\title{
Market Imperfections within the European Wheat Value Chain: The Case of France and the United Kingdom
}

\author{
Lukáš Čechura ${ }^{1, *}$ and Tinoush Jamali Jaghdani ${ }^{2}$ (D) \\ 1 Department of Economics, Faculty of Economics and Management, Czech University of Life Sciences Prague, \\ Kamýcká 129, 16500 Prague, Czech Republic \\ 2 Leibniz Institute for Agricultural Development in Transition Economies (IAMO), \\ 06120 Halle (Saale), Germany; Jaghdani@iamo.de \\ * Correspondence: cechura@pef.czu.cz; Tel.: +420-22438-2052
}

Citation: Čechura, L.; Jaghdani, T.J. Market Imperfections within the European Wheat Value Chain: The Case of France and the United Kingdom. Agriculture 2021, 11, 838. https://doi.org/10.3390/ agriculture11090838

Academic Editors: David Barling, Antonella Samoggia and Guðrún Ólafsdóttir

Received: 5 August 2021

Accepted: 25 August 2021

Published: 31 August 2021

Publisher's Note: MDPI stays neutral with regard to jurisdictional claims in published maps and institutional affiliations.

Copyright: (c) 2021 by the authors. Licensee MDPI, Basel, Switzerland. This article is an open access article distributed under the terms and conditions of the Creative Commons Attribution (CC BY) license (https:// creativecommons.org/licenses/by/ $4.0 /)$.

\begin{abstract}
The focus of this paper is on the analysis of market imperfections in the French and U.K. wheat value chains. We used mark-up and mark-down models and stochastic frontier analysis to estimate the degree of market imperfections in two completely different wheat-to-bread chains for two stages/sectors-milling and baking. Our results reveal some degree of market imperfections within the input and output markets for both the milling and baking sectors in France and the United Kingdom. However, the abuse of bargaining power is especially pronounced in the input market for the second stage of wheat processing, particularly in the French baking sector. However, we did not observe the expected positive association between the degree of market imperfections and company size except for a group of middle, large, and very large companies within the millers' input market. Small companies indicate considerably high values of "Lerner" / Lerner indices, suggesting a benefit from other sources of competitive advantage (such as quality, niche markets, etc.).
\end{abstract}

Keywords: market power; wheat; milling; baking; SFA; mark-down; mark-up; Lerner index

\section{Introduction}

With the European Union (EU)'s adoption of the directive of unfair trading practices (UTP) in the agri-food supply chain in 2019, the already ongoing discussion of the concentrations of agricultural and food supply chains reached a new level [1]. Availability of competition in the market and avoiding an increase in monopolies have been two key issues of concern among academics, policymakers, and general society, and these two topics have been under study for a number of years [2]. Based on the EU directive, it is fair to say that these concerns are also especially high in the food supply chain [1]. It is very important to know if there is a market imperfection in the supply chain. The availability of market power can eliminate any effects of support policies, such as floor pricing or deficiency payments [3]. Furthermore, some scholars suggest that market power in agricultural markets dampens any gains from trade reform policies compared to a situation of perfect competition [4]. The developments of food supply chains have been taken more seriously and received more attention from regulatory organizations and researchers after the food price developments of 2008 [5,6]. However, the issue of warning about concentration in food supply chains is older than the 2008 crisis and started with analyses by Sexton [7] and McCorrison [8], who noticed that industrialization and consolidation in the food system had increased [9]. In other words, the emergence of powerful food retailers, along with a continued increase in concentration among food manufacturers, raises the issues of bilateral oligopoly and countervailing power in the wholesale market [10]. Furthermore, the growth of global value chains (GVCs) or modern agri-food chains has also been accompanied by consolidation in agribusiness, food processing, and retailing [11]. As has been mentioned, competitiveness in agricultural markets has been an issue of concern for quite some time. 
Within the EU, a number of regulations have been put in place to address these issues. In 2013, for instance, the European Parliament approved regulations concerning completion rules for farmers (Regulation 1308/2013), also known as the "Common Market Organisation (CMO) Regulation" [12], which addresses the lack of bargaining power for atomized farmers and how to deal with a crisis in agricultural production [13]. Some sectors, such as olive oil, beef and veal, and certain arable crops were exempt from the antitrust prohibition. This means that producers' organizations are allowed to negotiate on behalf of their members in order to optimize production costs and achieve other objectives [14]. To put it more accurately, this regulation derogates from general EU anti-trust laws, which are defined in Articles 101 and 109 of the Treaty on the Functioning of the European Union (TFEU). Although exemptions are considered under the TFEU, this special attention given to the EU's agri-food sector shows the delicacy of bargaining power and competition within the European agricultural market [15]. In 2016, an Agricultural Markets Task Force [16] addressed the weakness of farmers relative to other actors in the food supply chain, since processors and retailers are more concentrated. They also recommended tackling the UTPs through new legislation. This finally ended with Directive 2019/633 on UTPs [1]. Apart from this general concern at the EU level, there are also country anti-trust authorities and market competition authorities that analyze developments in the market and deal with different scenarios based on field studies. Two of these organizations are the Autorite de la concurrence (Competition Authority) in France and the Bundeskartellamt (Federal Cartel Office) in Germany [6]. Since 2013, the Competition and Markets Authority (CMA), which was formed by merging the Office of Fair Trading and the Competition Commission, is the responsible authority in the United Kingdom [17]. Similar organizations can be found in other developed and developing countries.

While determining whether market concentration exists is an important step, so too is deciding how to address it in a sound way. The approaches for determining the market concentration and imperfections in food supply chains between different actors can fall into three categories. Generally speaking, the empirical approaches can be divided into 'structure', 'conduct', and 'performance' approaches $[18,19]$. The 'structure' approach refers to a simple way to test market structure by finding the share of the q largest firms $(C R q)$ or via the Herfindahl-Hirschman Index (HHI). For the first indicator, the concentration rate for four major enterprises in the target industry, or $C R_{4}$, is widely used, and for the latter one $(H H I)$, the sum of the quadratic value of all firms' market share is calculated $[18,20]$. However, these indicators that form the structure approach do not necessarily show the competitive conditions in a market [9], and economists have distanced themselves from the structure approach over recent decades [2]. The next category of market power approaches, which test firms' quantity and pricing behaviors, is called the 'conduct' approach [18]. This has also been named the New Empirical Industrial Organization (NEIO). A 'Mark-up', 'Mark-down', or 'Lerner' index are three indicators from this category [18]. This category of methods is a better indicator of firms' behavior, but it has also received some criticisms based on their underlying assumptions [19]. Thus, modifications and extensions to this approach have been offered by, for example, Kumbhakar et al. [21], based on stochastic frontier analysis (SFA), and by Hall [22], and later, De Loecker and Warzynski [23], based on the production function approach (PFA). The difficulty in these cases is the availability of adequate databases and estimations of rigorous econometric models of firms' prices and quantities. Furthermore, differing results are normally estimated by various methods from this category of approaches [19]. Our research falls under this category, as we applied the SFA methodology. The final category of approaches is called 'performance', which contains a range of methods, such as profit margin analysis, price transmission analysis (e.g., [24,25]), or official reports from anti-trust authorities [18]. Depending on data availability, researchers and responsible organizations use one or some of these methods. The data from different parts of the economy at very aggregated or disaggregated levels can be used for this type of analysis, which can lead to varying results. 
One recent analysis by the European Central Bank (ECB), which was based on different sectors of the economy and aggregated data, does not show a tremendous increase in concentration indicators in the EU [26]. This study can be categorized alongside other analyses that have also raised some doubts about the level of concentration and market power exertion within European food supply chains $[5,9,10,20,27]$. Generally speaking, the 'hourglass' is considered to be the shape of the EU's food supply chain, consisting of many farmers who provide inputs to a limited number of processors, wholesalers, and retailers, which then supply a large number of consumers [18]. This structure is vulnerable to market power abuse. In spite of all the concern regarding market concentration, some general review studies on food supply chains, especially in the United States and the EU, also conclude that the concentration in food supply chains is not present or is very mild $[5,9,10,20,27]$. However, using aggregated or disaggregated data, or using too many industries or specific industries can show differing results [20]. For instance, by using a conduct approach on the salmon industry in Norway, Jaghdani et al. [28] found much higher mark-ups for larger salmon farmers and processors compared to all actors consisting of small farms and exporters being included in the analysis. It can be said that, as contrasting results are evident, despite public interests, the results of empirical studies to date that have measured market imperfections are not satisfactory [5]. In spite of these shortages, depending on the data quality, methodology, and research question(s), these approaches can help us to determine the market structure, conduct, and performance.

In this study, we have focused on the wheat supply chains in France and the United Kingdom. The reasons for this selection are, first, the different structures between these two chains, and secondly, accusations towards the milling industry in the EU by anti-trust authorities in recent years. As members of the EU have cohesive behavior on the anti-trust issues and many regulations are defined at the level of the European Commission and European parliament, and as the milling industries are active across national borders of the EU, we provide some of the most critical cases in the EU's milling and bakery industry. In 2013, 23 milling enterprises in Germany, along with individuals and the German Milling Association (Verband Deutscher Mühlen e.V), were fined EUR 65 million by the Bundeskartellamt. They were accused of being involved with an agreement between 60 milling enterprises between 2001 and 2008, whereby milling company representatives were involved in regular agreements on price increases, customer allocation, and supply volumes. Furthermore, the agreements were applied to all forms of common wheat and rye flour, that is, to industrial customers such as bakery product manufacturers, bakery chains, artisan bakers, and the direct sale of flour in small packages (max. $1 \mathrm{~kg}$ packets) to food retailers. Furthermore, the companies coordinated capacity planning by shutting down mills or preventing the reopening of other mills [29,30]. In another case in 2012, France's Autorite de la concurrence fined key French flour milling entities approximately EUR 147 million for rigging the domestic market over a period of 40 years. Additionally, German and French milling enterprises were fined approximately EUR 96 million due to planned limiting of cross-border trade of packaged flour to the French retail market from 2002 to 2008, which reduced the competition [31]. In 2010 in the Netherlands, the Autoriteit Consument \& Markt (Authority for Consumers and Markets), or ACM, found 15 Dutch, Belgian, and German flour producers guilty of participating in a cartel involving several agreement activities. In total, they were fined EUR 81.6 million for their agreement to not take away each other's customers and make it harder for those customers to negotiate better prices [32]. In 2014, in France, a local federation of bakers with 26 independent bakers was fined after being found guilty of agreeing to raise the price of bread during the period immediately preceding the adoption of the Euro [33]. Additional cases of different food supply chain meddling can be found in the European Competition Network $(\mathrm{ECN})$ report [33]. As these examples show, there are possibilities of reorganizing the anti-competition activities in the European wheat-to-bread supply chains.

This paper continues with a literature review on the available studies on market structure, conduct, and performance in the wheat-to-bread supply chain. Afterwards, in 
Section 3, an analysis of the structures of milling and bakeries in France and the United Kingdom is presented. Sections 4 and 5 provide the theoretical background, empirical strategy, and data, and the results are presented in Section 6, followed by a discussion and conclusion.

\section{Literature Review}

Due to the importance of wheat-to-bread supply chains, market imperfection studies have been conducted over the last two decades, with the main focus on NEIO and price transmission approaches. It must be mentioned that price transmission and market integration are not usually in line with market imperfection and competitiveness. In other words, market imperfection does not necessarily mean imperfect price transmission in the food market [34].

Primarily, the concentration within the U.S. milling system has attracted much attention from other researchers, and the reduction in the number of U.S. flour mills over the last decades has been acknowledged [35]. The costs for storing, handling, and processing declined significantly with the economies of scale for wheat and other grains. Furthermore, for removing spelt hulls and other hulled grains, de-hullers with a larger capacity have an economic advantage over smaller, more labor-intensive equipment [36]. One of the primary studies in this field was by Brester and Goodwin [37]. Starting with the assumption that concentration in the U.S. milling industry can cause vertical and horizontal market prices to not be co-integrated, they studied co-integration testing procedures to assess horizontal and vertical price transmission. They found a long-run equilibrium relationship among wheat and flour prices and a strengthening of vertical price transmission as the market became more concentrated. Therefore, they could not find a causal relationship between market concentration and price integration. In another study by Stiegert [38], in which a profit function and margin estimation approach were used, the hypothesis of upstream and downstream market competitiveness within the U.S. hard wheat milling industry could not be rejected. Later on, Russo [39] found a level of oligopoly in the U.S. milling industry, as well as that this industry benefits from a deficiency payments policy. There is also a growing niche market for local and organic grain products in the U.S. [36], which is a different development compared to the concentration in the conventional wheat-to-bread supply chain.

As market power estimation methods have been developed, market imperfection has been studied for other countries as well. O'Donnell et al. [40] studied the upstream and downstream market imperfection in food product manufacturing for 13 grain and oilseed products in Australia. They used an NEIO approach for the analysis of 10-year periods, 1989-1990 and 1999-2000. They found that flour and cereal food product manufacturers exerted market power when purchasing wheat, barley, oats, and triticale. Furthermore, they found beer and malt manufacturers exerted market power when purchasing wheat and barley. The same phenomenon was found for other food product manufacturers when purchasing wheat, barley, oats, and triticale. In contrast, they did not find market imperfections in the downstream part of the supply chain for the selling of flour, other cereal foods, bread, and other bakery products. Market imperfection has also been studied in the European wheat-to-bread supply chain. Čechura et al. [41] studied the market imperfection in the European food industry, including the milling industry for the 2003-2012 period, using a mark-up and mark-down NEIO model. They used data on 24 EU member states covering slaughtering, fruit and vegetables, dairy, and milling. For the milling industry, they found higher markups compared to mark-downs. Therefore, they found mild market imperfections downstream of the milling industry compared to upstream. One of the latest studies on the wheat-to-bread supply chain is that by Perekhozhuk et al. [42]. They used Hall's approach [22] to test the market power in the Kazakh grain processing industry for the 2000-2011 period as well as three sub-periods of 2000-2004, 2004-2007, and 2008-2011. They could not reject the hypothesis of competitiveness for the upstream part of the supply 
chain for the whole period. However, a certain level of oligopsony was found for the 2008-2011 period.

As we have seen, different studies on market power with different methods and both aggregated and disaggregated data have found contrasting results in recent years, which makes further research vital. In addition, most of the market power studies for the wheat-to-bread supply chains are focused on one supply chain and one actor. In the present study, we focused on two completely different structures of wheat-to-bread supply chains in both the United Kingdom and France by using an SFA approach. The structure of the wheat-to-bread supply chains in the United Kingdom and France is presented in Section 3.

\section{Wheat-to-Bread Supply Chains in France and the United Kingdom}

Focusing on millers and baking, the United Kingdom and France have relatively different wheat-to-bread supply chains. Generally speaking, France produces more soft/hard wheat annually compared to the United Kingdom. The size of the wheat harvest in France was 29.5 million tons (MT) in 2020, which was $17 \%$ less than the five-year average previously due to rainfall shortages [43]. The United Kingdom harvests less wheat compared to France, but more wheat is milled into flour in the United Kingdom (see Tables A1 and A2). France is one of the major wheat exporters in the world, while the United Kingdom has a lower role in international wheat exports [44,45]. By focusing on domestic wheat-to-bread supply chains in both countries, we see obvious differences at the milling and baking stages, which are explained separately below.

\subsection{Milling}

In 2019, 384 mills controlled by 330 enterprises were documented in France (see Appendix A, Table A1). The available data shows that approximately 5 million tons of wheat are processed on French milling sites annually, which is mainly turned into flour for artisanal or industrial baking. Approximately 4 million tons of flour was produced in 2019 in France. There is evidence of a certain level of concentration in France from over the last decade. According to data from Meunerie Française (the National Association of French Milling), four enterprises with 32 milling units processed $50 \%$ of in-demand flour in 2019 (see Table 1). Additionally, in 2019, 34 milling units had the capacity of processing more than 50,000 tons each, for a potential total of 3.26 million tons of wheat (more than $65 \%$ of demand) (see Table 2). Nevertheless, very diverse types of milling entities exist in France that work at the national, multiregional, regional, or local levels (see Table 1). It must be added that a structural change in concentration can be acknowledged in the French milling industry. In 1987, there were a total of 1215 mills in France that produced 5 million tons of flour. At that time, the largest milling company was Grand Moulin de Paris, which had $15 \%$ to $20 \%$ of the market share and 14 mills under its control that were used to produce 0.9 million tons of flour. In addition, there were 17 mills that had a larger capacity of producing 50,000 tons per year, and more than 600 mills produced less than 1000 tons a year [46]. The structural change has been reported by different statistics. Miller Magazine, for example, reported that in 2014, the number of enterprises manufacturing flour reduced to a total of 372 , with 439 production plants in general. It was reported by Miller Magazine that 435 milling sites produced 4.38 million tons of flour in 2013 (similar to Table 1) and 439 milling sites produced 4.27 million tons of flour in 2014 [47]. 
Table 1. The structure of millers in France.

\begin{tabular}{|c|c|c|c|c|c|c|}
\hline & Area of Activity & 2019 & 2016 & 2013 & 2010 & 2008 \\
\hline \multirow{5}{*}{ Number of enterprises } & National & 4 & 4 & 4 & 4 & 4 \\
\hline & Multiregional & 13 & 14 & 14 & 11 & 9 \\
\hline & Regional & 54 & 48 & 51 & 60 & 69 \\
\hline & Departmental & 259 & 293 & 300 & 284 & 294 \\
\hline & Sum & 330 & 359 & 369 & 359 & 376 \\
\hline \multirow{5}{*}{ Number of milling sites } & National & 32 & 34 & 42 & 45 & NA \\
\hline & Multiregional & 31 & 35 & 37 & 28 & NA \\
\hline & Regional & 60 & 53 & 56 & 65 & NA \\
\hline & Departmental & 261 & 294 & 300 & 284 & NA \\
\hline & Sum & 384 & 416 & 435 & 422 & \\
\hline \multirow{5}{*}{$\begin{array}{l}\text { Amount of bread wheat } \\
\text { processed (MT) }\end{array}$} & National & 2.49 & 2.94 & 3.08 & 3.23 & 3.17 \\
\hline & Multiregional & 1.44 & 1.32 & 1.43 & 1.03 & 1 \\
\hline & Regional & 0.83 & 0.76 & 0.79 & 0.97 & 1.22 \\
\hline & Departmental & 0.26 & 0.29 & 0.32 & 0.35 & 0.35 \\
\hline & Sum & 5.02 & 5.31 & 5.62 & 5.58 & 5.74 \\
\hline
\end{tabular}

Table 2. The structure of milling sites in France.

\begin{tabular}{|c|c|c|c|c|c|c|}
\hline & Area of Activity & 2019 & 2016 & 2013 & 2010 & 2008 \\
\hline \multirow{7}{*}{ Number of milling sites } & Capacity & 2019 & 2016 & 2013 & 2010 & 2008 \\
\hline & $>50,000$ tons & 34 & 35 & 36 & 31 & 34 \\
\hline & $10,000-50,000$ tons & 48 & 52 & 63 & 69 & 68 \\
\hline & $5000-10,000$ tons & 33 & 27 & 28 & 31 & 43 \\
\hline & $1000-5000$ & 90 & 105 & 113 & 120 & 127 \\
\hline & $<1000$ & 179 & 197 & 195 & 171 & 179 \\
\hline & Sum & 384 & 416 & 435 & 422 & 451 \\
\hline \multirow{6}{*}{$\begin{array}{l}\text { Total size of wheat } \\
\text { process at milling } \\
\text { sites (MT) }\end{array}$} & $>50,000$ tons & 3.26 & 3.48 & 3.63 & 3.31 & 3.44 \\
\hline & $10,000-50,000$ ton & 1.25 & 1.31 & 143 & 1.65 & 1.6 \\
\hline & $5000-10,000$ tons & 0.24 & 0.2 & 0.21 & 0.26 & 0.3 \\
\hline & $1000-5000$ tons & 0.23 & 0.27 & 0.29 & 0.3 & 0.33 \\
\hline & $<1000$ tons & 0.05 & 0.05 & 0.05 & 006 & 0.07 \\
\hline & Sum & 5.03 & 5.31 & 5.61 & 5.58 & 5.74 \\
\hline
\end{tabular}

The structure of the milling industry is completely different in the United Kingdom. From approximately 14 million tons of annual wheat harvested in the United Kingdom, approximately 6.2 million tons is used by the flour milling industry to produce 5 million tons of flour. Approximately $85 \%$ of this flour is homegrown. The United Kingdom is a less important wheat exporter compared to France (see [49] and Appendix B, Table A2). Merchants are the suppliers of wheat to millers in the United Kingdom [50]. It seems that major changes have not happened in the U.K. milling industry over the last 20 years. In 2004, 31 industrial enterprises controlled 59 milling sites and processed 5.6 million tons of wheat to produce 4.4 million tons of flour. Rank Hovis McDougall and Archer Daniels Midland accounted for 50\% of flour production [50]. The statistics are not very 
different for 2018. According to the U.K. Flour Miller Association (previously called the National Association of British and Irish Millers (NABIM)), in 2018, there were 30 industrial enterprises operating 51 mills. The four largest enterprises accounted for approximately $65 \%$ of U.K. flour production. Many smaller millers have focused on niche markets for local breads [51] (We could not find such detailed data from available sources on milling sites and enterprises for the United Kingdom compared to France.).

By comparing the France and U.K. milling industries, we noticed two major points. The U.K. milling industry is more concentrated than the French industry, and it has undergone fewer structural changes over the last 20 years. As was said in the introduction, more concentration does not necessarily mean market power exertion.

\subsection{Baking}

The baking sector is the next major component of the wheat-to-bread supply chain, and it is the main consumer of flour from the milling industry. Finding the necessary data on all actors in the baking sector was difficult; however, we are able to paint a general picture based on the available data on the role of actors in the baking sector in France and the United Kingdom. According to the available statistics for 2019 [48], approximately 2.5 million tons of flour were used for baking purposes in France, with $56 \%$ used by traditional bakeries and artisanal pastry makers, $35 \%$ by industrial bakeries and pastry makers, and $9 \%$ by supermarkets (see Appendix A, Table A1). This shows that the role of small bakeries is very important in France. Table 3 shows a breakdown of the French baking sector from 2011 to 2019. The data provided by Passion Céréales shows that the traditional bakery has a stable role in the baking sector and no structural change can be accounted for (There are some slight differences between the amounts of flour used by different bakeries between what is reported by Meunerie Française and Passion Céréales, which could be due to estimation approaches.). However, certain levels of changes have been recognized by researchers from 1985 to 2005. According to Hill [52], the baguette, which is the main soft wheat product in France, was produced more from frozen dough rather than fresh dough in 2005 compared to 1985. Additionally, the volumes of bread produced by artisans decreased by $22 \%$ during the same period and the consumption of pre-baked loaves increased.

In the United Kingdom, nearly 11 million loaves are sold each day. Approximately $60-70 \%$ of the bread consumption is white and sandwiches account for $50 \%$ of overall bread consumption [53]. Furthermore, 2 million pizzas and 10 million cakes and biscuits are made in Britain every day [49]. In contrast to France, approximately $80-85 \%$ of the bread consumption in the United Kingdom is from industrial sources [50,53]. The available data from the U.K. Federation of Bakers Ltd. (FOB) shows that the U.K. baking sector can be broken down into industrial plant bakeries, in-store bakeries, and craft bakeries, with $15 \%$ of flour consumed by non-industrial bakeries [54]. The annual sale rate of the baking sector is GBP 3.5 billion [55]. According to the U.K. Craft Bakers Association (CBA), in 2014, 27,000 people were working in the U.K. baking sector [56]. Table 4 shows the structure of the U.K. baking sector. A study by Sharpe et al. [50] shows that, in 2006, the U.K. industrial bread sector was dominated by 11 companies operating 51 factories. The three biggest companies accounted for half of the bread market by volume. Furthermore, strong vertical integration was observed between millers and bakers. For instance, two of the largest plant bakers (Allied Bakeries and British Bakeries) are owned by two millers: Associated British Foods and Rank Hovis McDougall, respectively [50].

As we can see, the structure of the wheat-to-bread supply chain is completely different in the United Kingdom and France, with different actors at the two important stages of milling and baking. The motivation for this research is to look into the market power exertion and possible market imperfections between the two different supply chains. 
Table 3. The breakdown of the French baking sector.

\begin{tabular}{|c|c|c|c|}
\hline & 2019 & 2016 & 2011 \\
\hline \multicolumn{4}{|c|}{ Share of bread market (\%) } \\
\hline Artisan bakeries & $56.2 \%$ & $57 \%$ & $61.5 \%$ \\
\hline Industrial bakeries & $43.8 \%$ & $43 \%$ & $38.5 \%$ \\
\hline \multicolumn{4}{|c|}{ Statistics on bakeries } \\
\hline Number of bakeries & 35,000 & 35,000 & 35,100 \\
\hline Number of industrial bakeries & NA & 240 & 270 \\
\hline \multicolumn{4}{|c|}{ Number of employees } \\
\hline Artisan bakeries & 180,000 & 180,000 & 160,000 \\
\hline Industrial bakeries & 46,000 & 40,000 & 35,000 \\
\hline \multicolumn{4}{|c|}{ Flour production } \\
\hline Total flour production (MT) & 3.9 & 4.12 & 4.37 \\
\hline \multicolumn{4}{|c|}{ Flour consumption for bread production (MT) } \\
\hline Artisan bakeries (MT) & 1.27 & 1.35 & 1.52 \\
\hline Industrial bakeries (MT) & 0.83 & 0.87 & 0.9 \\
\hline In-store bakeries (MT) & 0.22 & 0.24 & 0.25 \\
\hline $\begin{array}{l}\text { Flour consumption for industrial biscuits, sandwich } \\
\text { breads, and rusk production (MT) }\end{array}$ & 1 & 1.13 & 1.23 \\
\hline \multicolumn{4}{|c|}{ Turnover (billion Euros) } \\
\hline Artisan bakeries & 11 & 11 & 11 \\
\hline Industrial bakeries (including exports) & 8.2 & 7.5 & 5 \\
\hline
\end{tabular}

Source: [57-59].

Table 4. The structure of the U.K. baking sector in 2014.

\begin{tabular}{ccc}
\hline Category & Size & Number \\
\hline Large industrial bakeries & More than 100 employees & 150 \\
\hline Medium-sized bakeries & 25-100 employees & 350 \\
\hline Small craft bakeries & Fewer than 25 employees & 4500 \\
\hline Source: [56]. &
\end{tabular}

\section{Theoretical Background}

Our theoretical models belong to the family of models under the new empirical industrial organization (NEIO) approach. In particular, we followed Bresnahan $[60,61]$ and Muth and Wohlgenant [62] and used the conjectural variation approach to develop a mark-down and mark-up model [41]. Our models are based on the profit maximization assumption, a behavioral standard assumption used in firm analysis. That is, for the mark-down model, we assumed that firms follow the criterion of cost minimization in the input market and at the same time, they maximize revenues on the output market.

\subsection{Mark-Down Model-Input Processing Market}

The profit function of $i$ th processor can be written as the following equation:

$$
\pi_{i}=\boldsymbol{R}\left(p, x_{i}, z_{i}, t\right)-w_{x} \cdot x i-w_{z}{ }^{\prime} z_{i}
$$

where $\pi_{i}$ is the profit of a processor $(i), p$ is a vector of product prices, $R\left(p, x_{i}, z_{i}, t\right)$ represents the revenue function, $x$ stands for raw material, $z$ for other inputs, $t$ is a time trend (a proxy 
variable for technical change), and $w$ represents the corresponding factor price. Then, the supply function of raw material is written in the following form:

$$
x=g\left(w_{x}, s\right) \text { or } w_{x}=g^{-1}(x, s)
$$

where $s$ stands for a vector of supply shifters and $x$ stands for the total supply of raw material. The corresponding inverse supply function is $w_{x}=g^{-1}(x, s)$. Then, the firstorder condition for profit maximization can be written as the following equation:

$$
\frac{\partial R\left(\boldsymbol{p}, x_{i}, \boldsymbol{z}\right)}{\partial x_{i}}-w_{x}-\frac{\partial g^{-1}(x, s)}{\partial x} \frac{\partial x}{\partial x_{i}} x_{i}=0
$$

or after rearrangement and using elasticities, as the following:

$$
\begin{aligned}
& w_{x}\left(1+\frac{\Theta}{\varepsilon}\right)=\frac{\partial R(p, x, z, t)}{\partial x}, \text { where } \\
& \varepsilon_{x}=\frac{\partial x}{\partial g^{-1}(x, \boldsymbol{s})} \frac{g^{-1}(x, \boldsymbol{s})}{x}=\frac{\partial \ln x}{\partial \ln w_{x}}<0
\end{aligned}
$$

or after rearrangement and using elasticities, $\varepsilon_{x}$ is the price elasticity of the raw material supply and $\Theta=\frac{\partial x}{\partial x_{i}} \frac{x_{i}}{x}$ is a conjectural elasticity providing information on the degree of oligopsonistic market power [61]. In particular, $\Theta=0$ represents perfect competition, while $\Theta=1$ characterizes a monopolistic market.

Assuming that other input prices are constant, then the optimal level of input use (in this case, raw materials) is given by the equality of the input (raw materials) price and its marginal revenue product:

$$
w_{x}=M R P_{x}=\frac{\partial R}{\partial x}
$$

Equation (5) represents the condition of perfect competition. However, if the processor abuses its bargaining power, it can charge a mark-down (i.e., $\Theta>0$ ) and the equality becomes inequality:

$$
w_{x}<M R P_{x}=\frac{\partial R}{\partial x}
$$

Furthermore, as shown by Kumbhakar et al. [21], for the output market, we may express Equation (6) analogically for the input market as the following:

$$
w_{x} \frac{X}{R}<M R P_{x} \frac{x}{R}=\frac{\partial R}{\partial x} \frac{x}{R}=\frac{\partial \ln R}{\partial x \ln }=\frac{\partial \ln D^{0}}{\partial x \ln x}
$$

The duality of the revenue $(R)$ and output distance $\left(D^{o}\right)$ functions [63] used in Equation (7) provides the opportunity to carry out the analysis when the dataset contains only information on the quantities of individual processors but not on prices [21].

\subsection{Mark-Up Model-Output Processing Market}

The mark-up model can be derived in a similar manner (see again Bresnahan $[60,61]$ and Muth and Wohlgenant [62]). The profit function of $i$ th processor (for one output) can be written as the following equation:

$$
\pi_{i}=\boldsymbol{p} \cdot y_{i}-\boldsymbol{C}\left(\boldsymbol{w}, y_{i}, \boldsymbol{t}\right)
$$

where $p$ stands for the price of the output, $y_{i}$ is the output of the processor $(i), \mathrm{w}$ represents a vector of input prices, $C\left(w, y_{i}, t\right)$ is the cost function of the $i$ th processor, and $t$ (time trend) is used as a proxy variable capturing technical change. Then, the corresponding first-order condition for profit maximization is expressed as the following equation:

$$
\frac{\partial f^{-1}(y, \mathbf{d})}{\partial y} \cdot \frac{\partial y}{\partial y_{i}} \cdot y_{i}+p-\frac{\partial C\left(\boldsymbol{w}, y_{i}, t\right)}{\partial y_{i}}=0
$$


or, in terms of elasticities,

$$
p \cdot\left(1+\frac{\Omega}{\varepsilon_{p}}\right)=\frac{\partial C\left(w, y_{i}, t\right)}{\partial y_{i}}
$$

where $\mathbf{d}$ stands for a vector of demand shifters, $\varepsilon_{p}=\frac{\partial y}{\partial f^{-1}(y, d)} \frac{p}{y}<0$ is a demand elasticity of the final product, and $\Omega=\frac{\partial y}{\partial y_{i}} \cdot \frac{y_{i}}{y}$ is a conjectural elasticity capturing the degree of oligopolistic market power, with $\Omega=0$ indicating competitive behavior and $\Omega=1$ characterizing monopolistic power. It follows from Equation (10) that

$$
p \geq \frac{\partial C\left(w, y_{i}, t\right)}{\partial y_{i}} \quad \text { for } \Omega \in[0 ; 1]
$$

That is, if $\Omega=0$, then we get a well-known profit maximization criterion for perfect competition, that is, the price of the product is equal to marginal costs. If $\Omega>0$, then the inequality in Equation (11) represents a certain degree of market imperfection; in particular, it shows that processors charge a mark-up. Following Kumbhakar et al. [21], expanding both sides of Equation (11) with revenue over cost ratios, and using the duality of the cost $(C)$ and input distance $\left(D^{I}\right)$ functions [63], we get the following equation:

$$
\frac{p \cdot y}{C} \geq \frac{\partial C\left(\boldsymbol{w}, y_{i}, t\right)}{\partial y_{i}} \cdot \frac{y}{C}=\frac{\partial \ln C}{\partial \ln y}=\frac{\partial \ln D^{I}}{\partial \ln y}
$$

\section{Material and Methods}

\subsection{Empirical Strategy}

Kumbhakar et al. [21] showed how to employ a stochastic frontier analysis (SFA) to measure the inequality in Equation (12). We followed their approach and transformed both inequalities in Equations (7) and (12) for distance function representations, adding a non-negative one-sided error term, as follows:

$$
\begin{gathered}
\frac{w_{x} \cdot x}{R}=\frac{\partial \ln D^{o}}{\partial \ln x}-u, u \geq 0 \text { and } \\
\frac{p \cdot y}{C}=\frac{\partial \ln D^{I}}{\partial \ln y}+u, u \geq 0
\end{gathered}
$$

Then, we assumed that the underlying transformation process can be well approximated by the translog input and output distance function. That is, we implicitly imposed a constant return to scale restriction, which is supported by the empirical literature [41]. With translog input and output distance functions, we get the following equations:

$$
\begin{gathered}
\frac{w_{x} x}{R}=\beta_{x}+\beta_{x t} t+\beta_{x x} \ln x+\beta_{z x}{ }^{\prime} \ln z-u \text { and } \\
\frac{p y}{C}=\alpha_{y}+\alpha_{y t} t+\alpha_{y y} \ln y+\beta_{x y}{ }^{\prime} \ln \widetilde{x}+u, \text { where } \\
\widetilde{X}_{j}=x_{j} / x_{J} \text { for } j=1, \ldots, J .
\end{gathered}
$$

Kumbhakar et al. [21] first applied a stochastic frontier approach in an estimation of the degree of market power in Equation (15). In this study, we used a two-step system GMM estimator [64] to address the endogeneity problem when estimating Equations (14) and (15). Moreover, we relied on the last advances in the SFA literature and decomposed a nonnegative one-sided error term to the transient $(\mu)$ and persistent $(\eta)$ part, that is, $u=\mu+\eta$, and then added a heterogeneity component to capture the differences in firms' technologies. This model specification is an analogy to the four-component stochastic frontier model [65]. The decomposition of the one-sided error term allows us to distinguish between market power and short-term deviations. That is, since market power has its origins in firm strategies, it is long-term in nature and as such, might not change considerably over time. That is why we related a measure of market power to the persistent component. On 
the other hand, the short-term deviations might be related, for example, to changes in processors' contracts.

That is, the models to be estimated are expressed as the following equations:

$$
\begin{gathered}
\frac{w_{x} x_{i t}}{R_{i t}}=\beta_{x i}+\beta_{x t} t+\beta_{x x} \ln x_{i t}+\beta_{z x}{ }^{\prime} \ln z-u_{i t}-\eta_{i}+v_{i t} \\
\frac{p y_{i t}}{C_{i t}}=\alpha_{y i}+\alpha_{y t} t+\alpha_{y y} \ln y_{i t}+\alpha_{x y}{ }^{\prime} \ln \widetilde{\boldsymbol{x}}-u_{i t}-\eta_{i}+v_{i t}
\end{gathered}
$$

where the subscript $i=1, \ldots$, I refers to the $i$ th processors and $t=1, \ldots, T$ denotes time. $v_{i t} \sim N\left(0, \sigma_{v}^{2}\right), \mu_{i t} \sim N^{+}\left(0, \sigma_{\mu}^{2}\right)$, and $\eta_{i} \sim N^{+}\left(0, \sigma_{\eta}^{2}\right)$ are assumed to be independent of each other and of regressors.

The models are estimated in four steps. We followed Bokusheva and Čechura [66] and employed a two-step system GMM in the first step to calculate an unbiased parameter estimate. Then, we used GMM residuals and a random-effects model to estimate transient, persistent, and heterogeneity components.

Finally, the relative mark-down (Equation (18)) and relative mark-up (Equation (19)) [21] are defined as the following equations:

$$
\sigma=\frac{M R P_{x}-w_{x}}{M R P_{x}}
$$

and

$$
\phi=\frac{p-M C}{M C}
$$

that can be estimated as

$$
\hat{\sigma}_{i}=\frac{\hat{\eta}_{i}}{\beta_{x_{i}}+\beta_{x t} t+\beta_{x x} \ln x_{i t}+\beta_{z x}{ }^{\prime} \ln z}
$$

and

$$
\hat{\varphi}_{i}=\frac{\hat{\eta}_{i}}{\alpha_{y_{i}}+\alpha_{y t} t+\alpha_{y y} \ln y_{i t}+\alpha_{x y}{ }^{\prime} \ln \widetilde{x}}
$$

or, in terms of the Lerner index (1934), as

$$
\begin{gathered}
" L "=\frac{M R P_{x}-w_{x}}{M R P_{x}}=\frac{\sigma}{1+\sigma} \\
L=\frac{P-M C}{P}=\frac{\varphi}{1+\varphi}
\end{gathered}
$$

For further reference on the relative mark-up estimate, see Kumbhakar et al. [21]. It must be mentioned that the Lerner index was originally defined for the output market only [67]. We redefined it for the input market.

\subsection{Data Used in this Study}

The Amadeus database, created and produced by Bureau van Dijk, was used as the main source of data (More information on the Amadeus database is provided at http:/ / www.bvdinfo.com, last accessed on 30 June 2021). The database contains financial information (especially financial reports) for private companies across Europe. This dataset consists of the companies who are obliged to publish balance sheets and profit loss accounts (cooperatives, joint stock companies, etc.). The dataset that we used in this study contains companies whose main activities (according to the NACE classification) are milling (10.6) and baking (10.7) in France and the United Kingdom. In addition, EUROSTAT was the source of price indices that were used for the deflation of monetary variables.

The panel dataset used for the analysis accounts for the period from 2006 to 2018 . Table 5 provides the information on the total number of observations for the milling and 
baking industries in France and the United Kingdom and their distributions over time. It was evident that we were dealing with an unbalanced panel dataset. However, the structure of the dataset represents an average of over $42 \%$ of mills in France $(51 \%$ between 2008 and 2015 and 10\% in the last three years, 2016-2018) and over $60 \%$ in the United Kingdom, which may provide a representative picture of the market imperfections in the French and U.K. wheat-to-bread value chain.

Table 5. Number of observations-milling and baking industries.

\begin{tabular}{|c|c|c|c|c|c|c|c|c|c|c|c|c|c|c|}
\hline \multicolumn{15}{|c|}{ Milling } \\
\hline & 2006 & 2007 & 2008 & 2009 & 2010 & 2011 & 2012 & 2013 & 2014 & 2015 & 2016 & 2017 & 2018 & Total \\
\hline France & 188 & 231 & 240 & 248 & 257 & 253 & 256 & 244 & 204 & 163 & 43 & 41 & 35 & 2403 \\
\hline U.K. & 23 & 28 & 32 & 40 & 40 & 40 & 37 & 39 & 38 & 35 & 29 & 28 & 27 & 436 \\
\hline \multicolumn{15}{|c|}{ Baking } \\
\hline & 2006 & 2007 & 2008 & 2009 & 2010 & 2011 & 2012 & 2013 & 2014 & 2015 & 2016 & 2017 & 2018 & Total \\
\hline France & 1239 & 1243 & 1244 & 1247 & 1247 & 1247 & 1247 & 1247 & 1247 & 1247 & 39 & 38 & 35 & 12,567 \\
\hline U.K. & 38 & 53 & 60 & 87 & 88 & 99 & 105 & 113 & 111 & 104 & 83 & 80 & 71 & 1092 \\
\hline
\end{tabular}

The mark-down model consists of the following variables: cost share (which is the material costs/revenue), materials (M), labor (L), and capital (C). The variables are defined as follows: Material costs are represented by the total cost of materials and energy consumption per company and revenue is the operating revenue (turnover) of the company. Materials are the total cost of materials and energy consumption per company that is deflated by the index of producer prices in the industry $(2010=100)$. Labor is represented by the cost of employees and is deflated by the consumer price index $(2010=100)$. Finally, capital is the book value of fixed assets and is deflated by the index of producer prices in the industry $(2010=100)$.

The mark-up model contains the following variables: revenue share (revenue/costs), output (y), normalized materials (M), and labor (L). Revenue is, again, represented by the operating revenue (turnover) of the company. Costs are calculated as the sum of labor costs, material costs, and capital costs. Labor costs are represented by the cost of employees, material costs are the total cost of materials and energy consumption per company, and capital costs are calculated as the book value of fixed assets multiplied by the interest rate according to the convergence criteria. Output is represented by the operating revenue (turnover) of the company and is deflated by the sectoral index of a particular output (milling/baking) processing price $(2010=100)$. Materials, labor, and capital are defined in the same way as in the case of the mark-down model. Material and labor are normalized by capital.

Thus, in our dataset, we rejected producers with fewer than four observations to comply with the requirements of the applied system GMM estimator. In addition, this procedure helped us to decrease the problem of the use of unbalanced panel data.

\section{Results}

Tables 6 and 7 provide the parameter estimates of the mark-down and mark-up models for the French and U.K. milling and baking industries. The results show an overall good fit of all models despite the fact that the parameter significance is poorer in the United Kingdom's models. In particular, most of the fitted parameters in the French mark-down and mark-up models are statistically significant at the 5\% significance level. The United Kingdom's mark-down models show a better fit compared to the mark-up ones, with a majority of significant parameters at least at the $10 \%$ significance level. The United Kingdom's mark-up models have only one significant parameter, the parameter for output. However, and more importantly, the models comply with the results of the test for overidentified restrictions (Hansen test). The test results indicate, in all cases, the validity of 
the models and the correct selections of the employed instruments, respectively. We used input variables as instruments lagged up to two periods for the equation in levels and up to three periods for the equation in differences. Then, year dummies and the size variable and year dummies and different firm characteristics were used as additional instruments.

Table 6. Mark-down and mark-up model estimates-milling.

\begin{tabular}{|c|c|c|c|c|c|c|}
\hline \multicolumn{7}{|c|}{ Mark-Down Model } \\
\hline & \multicolumn{3}{|c|}{ France } & \multicolumn{3}{|c|}{ U.K. } \\
\hline Variable & Coefficient & St. Dev. & $p$-Value & Coefficient & St.Dev. & $p$-Value \\
\hline $\mathrm{t}$ & 0.003 & 0.001 & 0.000 & 0.002 & 0.002 & 0.375 \\
\hline $\ln \_\mathrm{M}$ & 0.129 & 0.012 & 0.000 & 0.096 & 0.020 & 0.000 \\
\hline $\ln \_L$ & -0.106 & 0.018 & 0.000 & -0.052 & 0.020 & 0.013 \\
\hline $\ln \_C$ & -0.024 & 0.01 & 0.016 & -0.018 & 0.011 & 0.098 \\
\hline \multirow[t]{2}{*}{ constant } & 0.405 & 0.013 & 0.000 & 0.518 & 0.069 & 0.000 \\
\hline & & & $p$-value & & & $p$-value \\
\hline $\begin{array}{c}\text { Hansen test of } \\
\text { overid. restrictions }\end{array}$ & chi2 (273) & 255.61 & 0.768 & chi2 (192) & 38.31 & 1.000 \\
\hline \multicolumn{7}{|c|}{ Mark-Up Model } \\
\hline & \multicolumn{3}{|c|}{ France } & \multicolumn{3}{|c|}{ U.K. } \\
\hline Variable & Coefficient & St. Dev. & $p$-Value & Coefficient & St. Dev. & $p$-Value \\
\hline $\mathrm{t}$ & -0.002 & 0.001 & 0.066 & -0.001 & 0.003 & 0.725 \\
\hline $\ln \_y$ & 0.014 & 0.011 & 0.227 & -0.049 & 0.021 & 0.025 \\
\hline $\ln \_\mathrm{L}$ & 0.083 & 0.031 & 0.008 & 0.030 & 0.068 & 0.660 \\
\hline $\ln \_M$ & -0.098 & 0.023 & 0.000 & -0.035 & 0.051 & 0.496 \\
\hline \multirow[t]{2}{*}{ constant } & -1.449 & 0.025 & 0.000 & -1.480 & 0.211 & 0.000 \\
\hline & & & $p$-value & & & $p$-value \\
\hline $\begin{array}{l}\text { Hansen test of } \\
\text { overid. restrictions }\end{array}$ & chi2 (252) & 255.23 & 0.431 & chi2 (102) & 37.69 & 1.000 \\
\hline
\end{tabular}

Note: chi2 is the chi square of overidentification test; St. Dev. refers to standard deviation. Source: Authors' calculations.

Moreover, the parameter estimates in the second, third, and fourth steps of our procedure (see Section 4) are highly significant and provided very good overall statistical and econometric quality for all models. This held for the random effects models, which showed that the variation of the one-sided component is more pronounced than the variation in the random component for all cases, as well as for the estimates of the persistent part of the one-sided component. In particular, the estimate of the persistent component indicates that differences in non-competitive behavior among millers and bakers are important characteristics of these industries.

\subsection{Milling Industry}

Table 8 displays statistical characteristics of the relative mark-down, mark-up, and "Lerner" / Lerner indices for the mark-down and mark-up model (see Equation (22) for "Lerner" index or " $L$ " and Equation (23) for Lerner index or $L$ ). The relative mark-down (MD), mark-up (MU), as well as the "Lerner" / Lerner indices for input market and output market, provide us with a measure of the degree of market imperfections. Since the Lerner index is more frequently used in theoretical, as well as empirical analyses, we focus on the Lerner indices in the next parts of this section. In particular, if the value of the "Lerner" /Lerner index is close to zero, then the market is close to an environment of perfect competition. On the other hand, if the "Lerner"/Lerner index is close to one, then the market is characterized by monopsony/monopoly market power (see Section 4). 
Table 7. Mark-down and mark-up models estimates—baking.

\begin{tabular}{|c|c|c|c|c|c|c|}
\hline \multicolumn{7}{|c|}{ Mark-Down Model } \\
\hline \multirow[b]{2}{*}{ Variable } & \multicolumn{3}{|c|}{ France } & \multicolumn{3}{|c|}{ U.K. } \\
\hline & Coefficient & St. Dev. & $p$-Value & Coefficient & St. Dev. & $p$-Value \\
\hline $\mathrm{t}$ & -0.001 & 0.001 & 0.019 & 0.001 & 0.001 & 0.444 \\
\hline $\ln \_\mathrm{M}$ & 0.168 & 0.015 & 0.000 & 0.106 & 0.037 & 0.005 \\
\hline ln_L & -0.135 & 0.024 & 0.000 & -0.076 & 0.035 & 0.033 \\
\hline ln_C & -0.034 & 0.012 & 0.004 & -0.013 & 0.007 & 0.070 \\
\hline \multirow[t]{2}{*}{ constant } & 0.357 & 0.005 & 0.000 & 0.507 & 0.043 & 0.000 \\
\hline & & & $p$-value & & & $p$-value \\
\hline $\begin{array}{c}\text { Hansen test of } \\
\text { overid. restrictions }\end{array}$ & chi2 (61) & 66.16 & 0.303 & chi2 (192) & 130.75 & 1.000 \\
\hline \multicolumn{7}{|c|}{ Mark-Up Model } \\
\hline & \multicolumn{3}{|c|}{ France } & \multicolumn{3}{|c|}{ U.K. } \\
\hline Variable & Coefficient & St. Dev. & $p$-Value & Coefficient & St. Dev. & $p$-Value \\
\hline $\mathrm{t}$ & 0.012 & 0.002 & 0.000 & -0.002 & 0.002 & 0.378 \\
\hline $\ln \_y$ & 0.016 & 0.006 & 0.006 & -0.044 & 0.014 & 0.002 \\
\hline ln_L & 0.033 & 0.017 & 0.050 & -0.003 & 0.051 & 0.958 \\
\hline ln_M & -0.022 & 0.012 & 0.058 & -0.004 & 0.055 & 0.944 \\
\hline \multirow[t]{2}{*}{ constant } & -1.299 & 0.017 & 0.000 & -1.340 & 0.084 & 0.000 \\
\hline & & & $p$-value & & & $p$-value \\
\hline $\begin{array}{l}\text { Hansen test of } \\
\text { overid. restrictions }\end{array}$ & chi2 (181) & 203.12 & 0.124 & chi2 (209) & 128.21 & 1.000 \\
\hline
\end{tabular}

Note: chi2 is the chi square of overidentification test; St. Dev. refers to standard deviation. Source: Authors' calculations.

Table 8. Summary statistics—milling.

\begin{tabular}{lcccccccc}
\hline & \multicolumn{4}{c}{ France } & & \multicolumn{2}{c}{ U.K. } \\
\hline & Mean & Std. Dev & Min & Max & Mean & Std. Dev & Min & Max \\
\hline $\begin{array}{l}\text { Relative mark-down } \\
\text { "Lerner" index, } \\
\text { mark-down model }\end{array}$ & 0.256 & 0.102 & 0.000 & 0.679 & 0.146 & 0.081 & 0.000 & 0.391 \\
\hline $\begin{array}{l}\text { Relative mark-up } \\
\begin{array}{l}\text { Lerner index, } \\
\text { mark-up model }\end{array}\end{array}$ & 0.198 & 0.064 & 0.000 & 0.404 & 0.124 & 0.059 & 0.000 & 0.281 \\
\hline
\end{tabular}

Table 8 shows that the mean values of the indices are significantly different from zero. Moreover, the distributions of indices are relatively narrow in all models and slightly skewed toward smaller values. These figures indicate that we can find some degree of market imperfections in both the input as well as the out-processing markets. However, the imperfections are more pronounced for the input market. That is, we may find higher market imperfections in the relation between millers and farmers as opposed to the relation between millers and bakers. Moreover, we can observe that only a small number of companies in both countries are characterized by a considerably high degree of non-competitive behavior or bargaining power, respectively. Furthermore, our results show significant differences between the countries. In particular, the degree of market imperfections in the French input market is more pronounced than in the U.K. input market. On the contrary, the market imperfections in the output market are higher in the United Kingdom. In other words, the French output market is close to the competitive market behavior as opposed to 
the U.K. output market, which shows some degree of market imperfections, with a similar magnitude as the U.K. input market.

Table 9 presents the figures of the "Lerner"/Lerner indices according to the size of the company. The evidence shows another pattern as compared to our expectations. That is, we can observe higher Lerner indexes for small companies in the French input market as compared to medium and large companies. In addition, the value of the index is similar to the value of the very large companies. These results suggest that small companies are able to charge mark-down due to, for example, an effect of quality, a niche market, specialization, and/or diseconomies of scale. The other markets do not indicate significant positive relations between the size and degree of non-competitive behavior. However, if we omit small companies, we may find the support of the positive association between the value of the index and the size of the company among middle, large, and very large companies.

Table 9. Market power according to size-milling.

\begin{tabular}{ccccc}
\hline & & & France & \\
& “Lerner” Index: Mark-Down Model & \multicolumn{2}{c}{ Lerner Index: Mark-Up Model } \\
\hline Size & Mean & St. Dev. & Mean & St. Dev. \\
\hline Small & 0.217 & 0.060 & 0.081 & 0.053 \\
\hline Medium & 0.146 & 0.085 & 0.073 & 0.050 \\
\hline Large & 0.174 & 0.057 & 0.106 & 0.062 \\
\hline Very large & 0.228 & 0.067 & & Lerner Index: Mark-Up Model \\
\hline Size & & & Mean & St. Dev. \\
\hline Small & “Lerner” Index: Mark-Down Model & 0.000 & 0.000 \\
\hline Medium & Mean & St. Dev. & 0.242 & 0.157 \\
\hline Large & - & - & 0.086 & 0.065 \\
\hline Very large & 0.230 & 0.069 & 0.189 & 0.037 \\
\hline
\end{tabular}

Source: Authors' calculations.

\subsection{Baking Sector}

Statistical characteristics of the relative mark-down, relative mark-up, and "Lerner" / Lerner indices indicate a considerable degree of market imperfections for the bakers' input market (see Table 10). These findings are in line with the results for the milling mark-up models, indicating only a small degree of bargaining power for millers' output markets. That is, despite the fact that some millers may have a certain degree of bargaining power, the higher concentration of bargaining power is on the side of bakers who are able to charge a considerable mark-down with respect to millers. The Lerner indices for the output markets are significantly smaller as compared to the input market. The values are similar in both countries and suggest that bakers do not have considerable bargaining power on the output market. In other words, bakers seem to have only limited space for charging a mark-up.

The hypothesis of the positive relationship between the value of the "Lerner"/Lerner index and the size of the company can be rejected in all cases (see Table 11). In other words, we do not observe any significant positive correlations between the firm size and the bargaining power. However, we can, again, as in the case of the milling industry, observe high values of "Lerner" / Lerner indices for small companies. These findings can be explained by the fact that some small companies use different strategies as compared to their larger competitors (such as quality, niche markets, etc.) to charge a certain degree of mark-down/-up. 
Table 10. Summary statistics-bakeries.

\begin{tabular}{lcccccccc}
\hline & \multicolumn{4}{c}{ France } & & \multicolumn{2}{c}{ U.K. } \\
\hline & Mean & Std. Dev. & Min & Max & Mean & Std. Dev. & Min & Max \\
\hline $\begin{array}{l}\text { Relative mark-down } \\
\text { “Lerner” index, }\end{array}$ & 0.471 & 0.102 & 0.000 & 0.997 & 0.340 & 0.175 & 0.000 & 0.857 \\
mark-down model & 0.317 & 0.050 & 0.000 & 0.499 & 0.242 & 0.094 & 0.000 & 0.461 \\
\hline $\begin{array}{l}\text { Relative mark-up } \\
\begin{array}{l}\text { Lerner index, } \\
\text { mark-up model }\end{array}\end{array}$ & 0.167 & 0.085 & 0.000 & 0.572 & 0.171 & 0.129 & 0.016 & 0.604 \\
\hline
\end{tabular}

Source: Authors' calculations.

Table 11. Market power according to size-bakeries.

\begin{tabular}{lcccc}
\hline & & \multicolumn{2}{c}{ France } & \multicolumn{2}{c}{ Lerner Index: Mark-Up Model } \\
\hline Size & “Lerner” Index: Mark-Down Model & Mean & St. Dev. \\
\hline Small & Mean & St. Dev. & 0.225 & 0.005 \\
\hline Medium & 0.318 & 0.049 & 0.131 & 0.060 \\
\hline Large & 0.317 & 0.051 & 0.148 & 0.056 \\
\hline Very large & 0.289 & 0.059 & 0.067 \\
\hline & 0.246 & 0.063 & Lerner Index: Mark-Up Model & St. Dev. \\
\hline Size & & & Mean & 0.103 \\
\hline Small & “Lerner” Index: Mark-Down Model & 0.152 & 0.107 \\
\hline Medium & Mean & St. Dev. & 0.121 & 0.061 \\
\hline Large & 0.269 & 0.134 & 0.110 & 0.081 \\
\hline Very large & 0.227 & 0.104 & 0.177 & \\
\hline
\end{tabular}

Source: Authors' calculations.

\section{Discussion and Conclusions}

In this study, we estimated the relative mark-up and mark-down indicators and, accordingly, their "Lerner" /Lerner indices for the milling and baking sectors of the United Kingdom and France using the Amadeus database for the 2006-2018 period. In particular, we used mark-up and mark-down models derived from the conjectural variation approach and stochastic frontier analysis to estimate the degree of market imperfections. This study was motivated, firstly, by accusations directed towards the milling and baking industries within the EU, secondly, by the increasing concentration within these sectors over the last 40 years, and finally, by the different structures observed between France and the United Kingdom's wheat-to-bread supply chains. Our database covers a relatively high level of milling industry actors in both countries and an acceptable level of baking industry actors at the industrial level for both France and the United Kingdom.

The results of this market power study for the milling industry for both countries show a level of market imperfections for the two countries. Both mark-up and Lerner indices are more than 0.1 on average, although, for France, a higher level of imperfections is evident. This could be due to the availability of more merchants among farmers and the few milling sites that exist in the United Kingdom compared to France, where milling enterprises trade directly with farmers more. The highest values for market power indicators are also apparent for French millers. In contrast to mark-down, mark-up indicators show very low market imperfections in France and a certain level of bargaining power in the United Kingdom. Looking at the Lerner indices (mark-up and mark-down) with respect to the size of the firms, a certain level of bargaining power can be observed even with 
small and medium milling enterprises in France and the United Kingdom. As the level of concentration is higher in the British milling industry, small mills are rare there. However, a certain market power exertion is noticeable between smaller millers and farmers, which is probably due to their activities in niche markets. The level of mark-ups is not high in France, which is justifiable, considering more suppliers are available compared to the United Kingdom. In the baking sector, we see very low Lerner indices as mark-downs for France, but high ones for the United Kingdom.

We observed higher mark-downs for the baking industry and lower mark-up indices for both France and the United Kingdom. In the United Kingdom, both the milling and baking industries are concentered. However, the bargaining power of the British bakery industry with their flour suppliers is higher than the upstream millers' market power. We found lower mark-up values for the bakery industry, which are due to the power of retailers and market demand. Additionally, industrial bakeries are in competition with rivals and artisan bakeries. Nevertheless, smaller bakeries at the industry level show relatively high mark-ups in both countries, which could be due to the focus on producing smaller units in niche markets.

Compared to the latest study on market power issues within the EU milling industry using the NIEO approach (see [41]), we found higher mark-down values for the milling industries in the United Kingdom and France. We found almost similar mark-ups for France but higher market imperfections for the U.K. milling industry. There can be different reasons for this. One is that this study was focused more on larger milling enterprises compared to that of Čechura et al. [41], which included all enterprises in one model. A second reason could be improvements made to estimation approaches. Similar to the case studies of O Donnel et al. [40] in Australia and Russo [39] in the United States, we cannot accept the hypothesis of full competitiveness in wheat-to-bread supply chains in the United Kingdom and France. However, different to O'Donnell et al. [40] in Australia, who found only market imperfection at the input stage of the milling industry, we found certain low levels of market imperfections for both the United Kingdom and France, with different magnitudes at the input and output levels. Furthermore, opposite to O'Donnell et al. [40], we found market imperfections in the baking industry. Additionally, in contrast to Perekhozhuk et al. [42], we found persistent market imperfections in our data.

The results of this study could be improved if the amounts of annual wheat and flour processing (for both mills and bakeries) are added to the mark-up model both for the main and instrument equations. Additionally, determining the geographical position of the millers and major bakery industry players to test the spatial aspects of market power distribution at the regional level would also be valuable. As this data shows, competition authorities need to be aware of firms' conduct in agri-food sectors, as they have the possibility to exert their power in different ways.

Author Contributions: Conceptualization, L.Č.; methodology, L.Č.; software, L.Č.; validation, L.Č. and T.J.J.; formal analysis, L.C..; investigation, L.Č.; resources, L.C.; data curation, L.Č.; writingoriginal draft preparation, L.Č. and T.J.J.; writing—review and editing, L.Č. and T.J.J.; visualization, L.Č. and T.J.J.; supervision, L.Č.; project administration, L.Č. and T.J.J.; funding acquisition, L.Č. and T.J.J. All authors have read and agreed to the published version of the manuscript.

Funding: This research was part of the VALUMICS project "Understanding Food Value Chain and Network Dynamics" funded by the European Union's Horizon 2020 research and innovation program, under grant agreement no. 727243. (https:/ / valumics.eu/ (accessed on 30 August 2021)).

Institutional Review Board Statement: Not applicable.

Informed Consent Statement: Not applicable.

Data Availability Statement: The data were obtained from the CULS and are not available from the authors. The data can be bought from Bureau van Dijk-Moody's Analytics company.

Acknowledgments: The authors are grateful to Mary Wales for her proofreading support. 
Conflicts of Interest: The authors declare no conflict of interest. This publication reflects only the authors' views, and the EU Funding Agency is not responsible for any use that may be made of the information it contains.

\section{Appendix A}

Table A1. The wheat and flour production and milling industry in France (2008-2019).

\begin{tabular}{|c|c|c|c|c|}
\hline Items & 2019 & 2016 & 2013 & 2008 \\
\hline Total common what production (1000 tons) & 34,045 & 40,910 & 35,503 & NA \\
\hline Total durum wheat production (1000 tons) & 1795 & 1806 & 2383 & NA \\
\hline Size of bread wheat processed by milling (1000 tons) & 5000 & 5320 & 5620 & 5740 \\
\hline Total flour production (1000 tons) & 3930 & 4120 & 4380 & 4420 \\
\hline Number of mills & 384 & 416 & 435 & 451 \\
\hline Number of enterprises & 330 & 359 & 369 & 376 \\
\hline Bakeries and artisanal pastry makers (1000 tons) & 1266.61 & 1346.204 & 1441.367 & 1552.361 \\
\hline Industrial bakeries and pastry shops (fresh and frozen) (1000 tons) & 782.613 & 796.58 & 764.31 & 830.892 \\
\hline Supermarket bakery / pastries (1000 tons) & 206.907 & 221.809 & 232.205 & 240.311 \\
\hline Public sector(1000 tons) & 1.076 & 1.319 & 1.479 & 1.624 \\
\hline Total Bakeries (1000 tons) & 2257.206 & 2365.912 & 2439.361 & 2625.188 \\
\hline Sachets & 168.992 & 184.702 & 224.005 & 255.722 \\
\hline Industrial use (such as biscuits, sandwich bread) (1000 tons) & 1049.297 & 1029.395 & 1108.611 & 1075.319 \\
\hline Animal feed and gluten starch factories (1000 tons) & 94.259 & 81.738 & 63.738 & 61.83 \\
\hline Total other uses (1000 tons) & 1311.548 & 1295.835 & 1396.354 & 1392.871 \\
\hline Exported processed products (1000 tons) & 128,313 & 94,835 & 88,166 & 0 \\
\hline Total domestic market (1000 tons) & 3697.067 & 3756.582 & 3923.881 & 4018.059 \\
\hline Total export (EU and Non-EU) (1000 tons) & 195.532 & 393.501 & 564.432 & 687.525 \\
\hline Turnover in the milling industry (million Euro) & 1700 & 1770 & 2240 & 2180 \\
\hline Export value (million Euro) & 111.7 & 160 & 254 & 268 \\
\hline Employers & 6700 & 6700 & 6000 & 6229 \\
\hline
\end{tabular}

Source: $[48,68]$.

\section{Appendix B}

Table A2. The wheat and flour production and milling industry in U.K. (2008-2019).

\begin{tabular}{|c|c|c|c|c|}
\hline Items & 2019 & 2016 & 2013 & 2008 \\
\hline Total wheat production (1000 tons) & 13,555 & 16,506 & 13,261 & 13,221 \\
\hline Imports (1000 tons) & 1858 & 1509 & 2956 & 1441 \\
\hline Exports (1000 tons) & 358 & 2848 & 737 & 1598 \\
\hline Total wheat milled (1000 tons) & 6084 & 6551.2 & 6581.3 & 5973 \\
\hline Number of mills & 51 & & 53 & 59 \\
\hline Number of enterprises & 30 & & 31 & 31 \\
\hline Home-grown wheat milled (1000 tons) & 5033.5 & 5616 & 4787 & 4774.5 \\
\hline Imported wheat milled (1000 tons) & 1050.8 & 935.2 & 1794.1 & 1198.6 \\
\hline White bread flour (1000 tons) & 2454.8 & 2548.3 & 2545.5 & 2409.3 \\
\hline Brown bread flour (1000 tons) & 49.8 & 51.7 & 93.5 & 128.3 \\
\hline Whole meal bread flour (1000 tons) & 253.4 & 296.5 & 315.1 & 292.9 \\
\hline Total bread making flour (1000 tons) & 2758.2 & 2896.3 & 2954 & 2830.6 \\
\hline Biscuit flour (1000 tons) & 472.8 & 422.9 & 552.3 & 535.8 \\
\hline Cake flour (1000 tons) & 90.1 & 115.1 & 119.3 & 85.7 \\
\hline Household flour (1000 tons) & 83.8 & 118.8 & 128.9 & 127.9 \\
\hline Food ingredients flour (1000 tons) & 401.7 & 263 & 195 & 201.4 \\
\hline Other flour (1000 tons) & 1022.6 & 1367.8 & 1191.3 & 928 \\
\hline Total flour produced (1000 tons) & 4828.9 & 5184.1 & 5140.9 & 4709.2 \\
\hline
\end{tabular}




\section{References}

1. European Commission. Directive (EU) 2019/633 of the European Parliament and of the Council of 17 April 2019 on unfair trading practices in business-to-business relationships in the agricultural and food supply chain. Off. J. Eur. Union 2019, L111, 59.

2. Berry, S.; Gaynor, M.; Scott Morton, F. Do Increasing Markups Matter? Lessons from Empirical Industrial Organization. J. Econ. Perspect. 2019, 33, 44-68. [CrossRef]

3. Russo, C.; Goodhue, R.E.; Sexton, R.J. Agricultural Support Policies in Imperfectly Competitive Markets: Why Market Power Matters in Policy Design. Am. J. Agric. Econ. 2011, 93, 1328-1340. [CrossRef]

4. McCorriston, S. Competition, Agricultural Trade Reform and Developing Countries. Margin J. Appl. Econ. Res. 2011, 5, 31-46. [CrossRef]

5. Perekhozhuk, O.; Glauben, T.; Grings, M.; Teuber, R. Approaches and methods for the econometric analysis of market power: A survey and empirical comparison. J. Econ. Surv. 2017, 31, 303-325. [CrossRef]

6. OECD. Competition Issues in the Food Chain Industry; Organisation for Economic Co-operation and Development (OECD): Paris, France, 2014.

7. Sexton, R.J. Industrialization and Consolidation in the U.S. Food Sector: Implications for Competition and Welfare. Am. J. Agric. Econ. 2000, 82, 1087-1104. [CrossRef]

8. McCorriston, S. Why should imperfect competition matter to agricultural economists? Eur. Rev. Agric. Econ. 2002, 29, 349-371. [CrossRef]

9. Sheldon, I.M. The competitiveness of agricultural product and input markets: A review and synthesis of recent research. J. Agric. Appl. Econ. 2017, 49, 1-44. [CrossRef]

10. Sexton, R.J.; Xia, T. Increasing concentration in the agricultural supply chain: Implications for market power and sector performance. Annu. Rev. Resour. Econ. 2018, 10, 229-251. [CrossRef]

11. Swinnen, J.; Olper, A.; Vandevelde, S. From unfair prices to unfair trading practices: Political economy, value chains and 21st century agri-food policy. Agric. Econ. 2021. [CrossRef]

12. European Commission. Regulation (EU) No 1308/2013 of the European Parliament and of the Council of 17 December 2013 establishing a common organisation of the markets in agricultural products and repealing. Off. J. Eur. Union 2013. Available online: https: / / eur-lex.europa.eu/legal-content/EN/TXT/?uri=CELEX\%3A32013R1308 (accessed on 16 July 2021).

13. Chauve, P.; Parera, A.; Renckens, A. Agriculture, Food and Competition Law: Moving the Borders. J. Eur. Compet. Law Pract. 2014, 5, 304-313. [CrossRef]

14. Sepe, G. The reform of the common organisation of the markets in agricultural products and the role of competition agencies. Antitrust Public Policies 2014, 1. [CrossRef]

15. European Commission. Report from the Commission to the European Parliament and the Council The application of the Union competition rules to the agricultural sector. Off. J. Eur. Union 2018.

16. Agricultural Markets Task Force Improving market outcomes-Enhancing the position of farmers in the supply chain. DG AGRI Eur. Comm. 2016.

17. Freeman, P. The Competition and Markets Authority: Can the whole be greater than the sum of its parts? J. Antitrust Enforc. 2013, 1, 4-23. [CrossRef]

18. Deconinck, K. Concentration and Market Power in the Food Chain; OECD Food, Agriculture and Fisheries Papers: Paris, France, 2021.

19. Koppenberg, M.; Hirsch, S. Markup estimation: A comparison of contemporary methods at the example of European food retailers. Agribusiness 2021, agr.21711. [CrossRef]

20. Nes, K.; Colen, L.; Ciaian, P. Market Power in Food Industry in Selected EU Member States; Publications Office of the European Union: Luxembourg, 2021.

21. Kumbhakar, S.C.; Baardsen, S.; Lien, G. A New Method for Estimating Market Power with an Application to Norwegian Sawmilling. Rev. Ind. Organ. 2012, 40, 109-129. [CrossRef]

22. Hall, R.E. The Relation between Price and Marginal Cost in U.S. Industry. J. Polit. Econ. 1988, 96, 921-947. [CrossRef]

23. De Loecker, J.; Warzynski, F. Markups and Firm-Level Export Status. Am. Econ. Rev. 2012, 102, 2437-2471. [CrossRef]

24. Cavicchioli, D. Detecting market power along food supply chains: Evidence and methodological insights from the fluid milk sector in Italy. Agriculture 2018, 8, 191. [CrossRef]

25. Grau, A.; Hockmann, H. Market power in the German dairy value chain. Agribusiness 2018, 34, 93-111. [CrossRef]

26. Cavalleri, M.C.; Eliet, A.; McAdam, P.; Petroulakis, F.; Soares, A.; Vansteenkiste, I. Concentration, Market Power and Dynamism in the Euro Area; European Central Bank (ECB): Frankfurt am Main, Germany, 2019.

27. McCorriston, S. Poliocy Roundtable: Competition Issues in the Food Chain Industry; OECD: Paris, France, 2014.

28. Jaghdani, T.J.; Čechura, L.; Ólafsdóttir, G.; Thakur, M. Market power in Norwegian Salmon Industry. In Proceedings of the Society for Economic and Social Sciences of Agriculture (GEWISOLA), Halle, Germany, 23-25 September 2020. [CrossRef]

29. Michels, M. Das Mühlenkartell in Deutschland-Eine ökonometrische Analyse. Ber. Über Landwirtsch. Z. Für Agrar. Und Landwirtsch. 2020, 98. [CrossRef]

30. Bundeskartellamt Bundeskartellamt Concludes Proceedings against Flour Mills and Imposes Fines Totaling More than 65 Million Euros. Available online: https://www.bundeskartellamt.de/SharedDocs/Meldung/EN/Pressemitteilungen/2013/19_02_201 3_Mühlenkartell.html (accessed on 20 July 2021). 
31. Landauro, I. French Flour Industry Hit With Fine. Wall Str. J. 2012. Available online: https://www.wsj.com/articles/SB1000142 4052702304537904577279422564717622 (accessed on 16 July 2021).

32. ACM Fine Cartels Flour Producers. Available online: https://www.acm.nl/en/publications/publication/3975/Fine-cartelsflour-producers (accessed on 20 July 2021).

33. ECN Report on Competition Law Enforcement and Market Monitoring Activities by European Competition Authorities in the Food Sector; European Competition Network (ECN): Brussels, Belgium, 2012.

34. Weldegebriel, H.T. Imperfect Price Transmission: Is Market Power Really to Blame? J. Agric. Econ. 2004, 55, 101-114. [CrossRef]

35. Ollinger, M.; Nguyen, S.V.; Blayney, D.; Chambers, B.; Nelson, K. Structural Change in the Meat, Poultry, Dairy, and Grain Processing Industries; Economic Research Service (ERS): Washington, DC, USA, 2005.

36. Baker, B.P.; Russell, J.A. Capturing a Value-Added Niche Market: Articulation of Local Organic Grain. Am. J. Agric. Econ. 2017, 99, 532-545. [CrossRef]

37. Brester, G.W.; Goodwin, B.K. Vertical and Horizontal Price Linkages and Market Concentration in the U.S. Wheat Milling Industry. Appl. Econ. Perspect. Policy Former. Rev. Agric. Econ. 1993, 15, 507-519. [CrossRef]

38. Stiegert, K.W. The producer, the baker, and a test of the mill price-taker. Appl. Econ. Lett. 2002, 9, 365-368. [CrossRef]

39. Russo, C. Deficiency Payments and Market Power: Effects of Imperfect Competition on Welfare Distribution and Decoupling. In Proceedings of the 2007 Annual Meeting, Portland, Oregon, 29 July-1 August 2007.

40. O'Donnell, C.J.; Griffith, G.R.; Nightingale, J.J.; Piggott, R.R. Testing for market power in the Australian grains and oilseeds industries. Agribusiness 2007, 23, 349-376. [CrossRef]

41. Čechura, L.; Hockmann, H.; Kroupová, Z. Market Imperfections in the European Food Processing Industry; Leibniz Institute for Agricultural Development in Transition Economies: Halle, Germany, 2014. Available online: http://www.compete-project.eu/ publications / working-papers.html (accessed on 16 July 2021).

42. Perekhozhuk, O.; Chezhia, G.; Glauben, T. Testing for oligopsony power in the Kazakh grain processing industry: A Hall approach. In Proceedings of the 30th International Conference Agricultural Economy (ICAE), Vancouver, BC, Canada, 28 July-2 August 2018. [CrossRef]

43. FranceAgriMer/ARVALIS. French Milling Wheat Quality; L'Établissement national des produits de l'agriculture et de la mer: Paris, France, 2020.

44. FAO FAOSTAT/ Data. Available online: http://www.fao.org/faostat/en/\#data (accessed on 27 July 2021).

45. ITC Trade Map. Trade Statistics for International Business Development. Available online: https:/ /www.trademap.org/Index. aspx (accessed on 27 July 2021).

46. Wilson, W.W.; Hill, L.D. The Grain Marketing System and Wheat Quality in France; North Dakota State University: Fargo, ND, USA, 1989.

47. Miller Magazine Grain and Flour Market in France and Germany. Available online: https://millermagazine.com/english/grainand-flour-market-in-france-and-germany/.html (accessed on 16 July 2021).

48. Meunerie Française Fiche Statistiques 2008-2019. Available online: https://www.meuneriefrancaise.com/Default.aspx?lid=1\& rid=144\&rvid=144 (accessed on 16 July 2021).

49. UK Flour Millers Statistics. Available online: https:/ / www.ukflourmillers.org/statistics (accessed on 16 July 2021).

50. Sharpe, R.; Barling, D.; Lang, T. Ethical Traceability in the UK Wheat-Flour-Bread Chain. In Ethical Traceability and Communicating Food; Coff, C., Barling, D., Korthals, M., Nielsen, T., Eds.; Springer: Dordrecht, The Nethelands, 2008; Volume 15, pp. $125-165$.

51. NABIM. Flour Milling in the UK, Facts and Figurs 2018; National Association of British and Irish Millers (NABIM): London, UK, 2018.

52. Hill, V. The bread VC: Its health impact and structure in France and the U.S.; Springer: London, UK, 2014; ISBN 978-3-319-04250-3.

53. UK Flour Millers Flour \& Bread Consumption. Available online: https://www.ukflourmillers.org/flourbreadconsumption (accessed on 16 July 2021).

54. fob About the Bread Industry, UK Bakery Market. Available online: https://www.fob.uk.com/about-the-bread-industry/ (accessed on 19 July 2021).

55. Fob Industry Facts. Available online: https://www.fob.uk.com/about-the-bread-industry/industry-facts/ (accessed on 19 July 2021).

56. CBA Market Information. Available online: https://www.craftbakersassociation.co.uk/about/market-information/ (accessed on 19 July 2021).

57. Passion Céréales. Des chiffres et des Céréales: L'essentiel de la Filière (Édition 2013); Passion Céréales: Paris, France, 2013.

58. Passion Céréales. Des chiffres et des Céréales: L'essentiel de la Filière (Édition 2017); Passion Céréales: Paris, France, 2017.

59. Passion Céréales. Des chiffres et des Céréales: L'essentiel de la Filière (Édition 2020); Passion Céréales: Paris, France, 2020.

60. Bresnahan, T.F. The oligopoly solution concept is identified. Econ. Lett. 1982, 10, 87-92. [CrossRef]

61. Bresnahan, T.F. Empirical studies of industries with market power. In Handbook of Industrial Organization; Schmalensee, R., Willig, R., Eds.; Elsevier: Amsterdam, The Netherlands, 1989; Volume 2, pp. 1011-1057, ISBN 978-0-444-70435-1.

62. Muth, M.K.; Wohlgenant, M.K. Measuring the degree of oligopsony power in the beef packing industry in the absence of marketing input quantity data. J. Agric. Resour. Econ. 1998, 24, 299-312.

63. Shephard, R.W. Theory of Cost and Production Functions; Princeton University Press: Princeton, NJ, USA, 1970; ISBN 9780691620800. 
64. Blundell, R.; Bond, S. Initial conditions and moment restrictions in dynamic panel data models. J. Econom. 1998, 87, 115-143. [CrossRef]

65. Tsionas, E.G.; Kumbhakar, S.C. Firm heterogeneity, persistent and transient technical inefficiency: A generalized true randomeffects model. J. Appl. Econom. 2014, 29, 110-132. [CrossRef]

66. Bokusheva, R.; Čechura, L. Evaluating Dynamics, Sources and Drivers of Productivity Growth at the Farm Level; Organisation for Economic Co-operation and Development (OECD): Paris, France, 2017.

67. Lerner, A.P. The Concept of Monopoly and the Measurement of Monopoly Power. Rev. Econ. Stud. 1934, 1, 157-175. [CrossRef]

68. FranceAgriMer France Cereal Balance 2012-2019. Available online: https:/ / www.franceagrimer.fr/filiere-grandes-cultures / Cereales/Eclairer/Etudes-et-Analyses/Chiffres-et-bilans (accessed on 16 July 2021).

69. AHDB UK Human and Industrial Cereal Usage. Available online: https://ahdb.org.uk/cereals-oilseeds/uk-human-industrialcereal-usage (accessed on 16 July 2021).

70. Smith, J.; Barling, D. Case Study: UK Wheat to Bread Supply Chain. In EU Finaced Project: Global and Local Food Assessment: A Multidimensional Performance-Based Approach (GALMUR); GALMUR: London, UK, 2014. 